Article

\title{
An Empirical Analysis of Students' Involvement and Exit Behaviors in College Organizations: The Case of Nanjing Agricultural University in China
}

\author{
Qi Zhang ${ }^{1}$, Yubing Fan ${ }^{2} \mathbb{D}$ and Mingyang Zhang ${ }^{3, *}$ \\ 1 College of Engineering, Nanjing Agricultural University, Nanjing 210031, Jiangsu, China; \\ zhangqi615600@126.com \\ 2 Texas A\&M AgriLife Research, Vernon, TX 76384, USA; yubing.fan@ag.tamu.edu \\ 3 School of Business, Nanjing University of Information Science and Technology, Nanjing 210044, Jiangsu, \\ China \\ * Correspondence: 002668@nuist.edu.cn
}

Received: 8 September 2018; Accepted: 26 October 2018; Published: 29 October 2018

\begin{abstract}
Student organization is considered an important approach for the sustainable development of ideological and political education, and it helps construct learning style and campus culture. This research studies college students' motivations for their involvement and exit behaviors. Using a binary choice model, we analyze critical factors affecting the involvement and exit behaviors of college students based on social cognition theory, Maslow's hierarchy of needs, and expectancy theory. On the one hand, our results show active cognition is most influential for the involvement behavior, followed by personal interest. Meanwhile, active cognition is positively affected by mother's higher education level and senior students' influence. Respondents who agree that joining organizations brings closer relations with teachers and other students as well as promoting heterosexual communication are more likely to join. On the other hand, the most influential factor for the exit behavior is unclear promotion mechanisms. Low-quality activities and wasting time with organizations cause students to quit. Moreover, lack of training opportunities and professional guidance dampens members' enthusiasm. Complicated interpersonal relations, bureaucratic style, entering a higher grade and changing psychology cause some members to quit and further affect organizational learning. We provide additional insights on management strategies towards organization sustainability, such as improving leader selection and building harmonious interpersonal relations.
\end{abstract}

Keywords: university student organizations; involvement and exit; motivation and cognition; love and belonging needs; sustainability

\section{Introduction}

With the development of the market economy, China's economic development trends, organizational forms, employment, and income distribution are increasingly diversified. The impact of the profit-seeking nature of the market economy, cultural and pluralistic values, and unidentified information on the Internet challenge the sustainable development of ideological and political education in colleges. Many events, such as college loans using nude photos, frequent suicides, fraudulent theses, and sudden deaths in physical examinations at some universities in China, have led to media attention and public concerns. Additionally, it is particularly concerning that undergraduates do not have appropriate attitudes, beliefs and perceptions regarding sustainable college life, learning and the environment. Chaplin et al. [1] found though university students believed sustainable living was important, yet the understanding level was low and there was a wide value-action gap. What is more, the most significant barrier was the displacement of responsibility for sustainable living to 
other people or organizations. The findings of Eagle et al. [2] also reflected a naïve awareness of the potential impacts of individual activities to environmental sustainability. College students generally show a tendency to regard such issues as beyond their personal control and to view solutions as being the responsibility of others. Lambrechts et al. [3] added insights regarding college students' attitudes toward sustainability. They identified four different segments of students according to their attitudes toward sustainability issues: Moderate problem solvers, pessimistic non-believers, optimistic realists, and convinced individualists. These issues have become practical concerns faced by ideological and political education and threaten the sustainability of higher education $[4,5]$.

High-quality participation in college organizations [6] not only improves students' comprehensive ability, but also helps foster morally sound values and outlook on the world and life for young people. Meanwhile, student organization is considered an important approach for the sustainable development of ideological and political education. By constructing a learning style and campus culture [7], students can be equipped with necessary competences including improved awareness of responsibility and emotional intelligence to address wicked sustainability challenges [8-10], and help improve the sustainability of organizations and colleges [11-17]. However, undergraduate students who participate in organizations present a decreasing trend as the grade increases: The first year is the peak period for students to join organizations; most sophomores quit organizations one after another; the juniors remaining in organizations are extremely rare; almost no seniors remain in organizations. Take Nanjing Agricultural University (NJAU) as an example, the survey finds about $86 \%$ of the respondents said they joined one or more organizations, of which $39 \%$ have quit (this survey excludes senior students). The high participation rate and high quit rate are true reflections of college organization involvement and exit behaviors at the Chinese universities. Meanwhile, fast-changing and dynamic societal and business environments make it more imperative than ever for student organizations to adapt. Consequently, it is particularly important to study undergraduate students' motivations for their involvement and exit behaviors.

In the past few decades, the traditional role of universities as centers for the creation and transmission of knowledge has become obsolete [18]. Brennan [19] postulates that universities should become places for the transformation of people and society, as well as enabling young people to acquire the competences that they need to live sustainably at personal, professional and community levels. Student organization is a means of student management in higher education, and many scholars are focused on the advantages of involvement in organization management. They hold the view that participation in organizations can develop members' leadership, improve students' preparedness for future jobs, increase cross-racial interaction, and generate post-college civic outcomes [20-25]. In addition, some particular student organizations have attracted scholars' attention. Opinions vary among scholars regarding Greek life, religious and ethnic student organizations. Some scholars [26-28] mention that participating in such groups and organizations hinder students from developing friendships with others. Von George [29] considers student organizations as a venue for cross-racial interaction, and points out that participation patterns in certain organizations may lead to a lower level of inter-racial friendship. Additionally, Chinese scholars have conducted much research regarding student organization from the perspectives of history, status [30,31], types [32], features [33], activity quality [34,35], functions [32,36-38], management mode, development direction, reasons for involvement or exit [39], existing problems and suggestions [40]. However, these studies mainly focus on theoretical elaboration and qualitative analysis of statistical survey [33,39], while lacking empirical analysis.

A number of other studies contribute to organizational change management [41,42]. For example, Gea et al. [43] examine and explore how Binus Industrial and Information Business Club manages and develops multicultural attitudes within the organization. Agarwal et al. [44] investigate how a student organization dedicated to serving students with disabilities at a predominately Hispanic serving university supports disabled students who feel isolated from campus life and activities. Kezaret et al. [45] think that an emphasis should be given to the social change-oriented leadership capacity 
for students to participate in the organizations. Munoz et al. [46] use an experiential learning theory for attracting and retaining members in student organizations. Martindale et al. [47] investigate professional values as a factor to influence involvement in social work student organizations. In order to develop an in-depth understanding of organizational change processes for sustainability, Hoover and Harder [48] carry out a meta-ethnographic synthesis of 13 qualitative studies. They suggest to recognize existing tensions and contradictions through reflexive practices and genuine dialogues as well as to develop flexible structures and moving towards "double loop" learning within institutions.

While the above studies discuss the contributions of involving in student organizations and organizational management, the factors affecting student involvement and exit behaviors in university organizations are understudied. To achieve the function of sustainable development of ideological and political education through student organizations, the purpose of this research is to understand the factors influencing student organization involvement and exit behaviors. Given the importance of student involvement in organizations, this paper adds to the literature by analyzing the effects of factors to prevent large-scale exits, enhance benefits of organization involvement, and achieve the sustainability of higher education [49]. Furthermore, studies in China often use qualitative analyses to investigate the reasons for student organization involvement and exit behaviors. Thus an empirical study can provide additional insights on the management strategies of student organizations.

\section{A Theoretical Framework}

\subsection{Involvement Behavior Based on the Social Cognition Theory}

Social cognition theory, developed by German psychologist Kaufka, points out that people will not passively face the multitude of things in the world, instead, they organize their perceptions, thoughts and beliefs into simple, meaningful forms [50]. This peculiar form affects an individual's behavior in all situations, especially social situations. Based on this theory, it can be inferred that undergraduate students' cognition of organizations may be an important factor influencing their involvement and exit behaviors. It is obvious that students will tend to choose the organizations that they have a good understanding of and interest in. Specifically, it encourages them to participate if they get more information about the organization, are introduced to the organization by senior students [51], or suggested to join by their parents [52,53].

\subsection{Involvement and Exit Behaviors Based on Maslow's Hierarchy of Needs}

The hierarchy of needs, proposed by Abraham Maslow, suggests human needs can be divided into five levels from low to high, that is, physiological needs, security needs, love and belonging needs, esteem needs, and self-actualization [54]. The realization and satisfaction of needs at each level determines the realm or extent of individual personality development. The theory clarifies the sources and driving forces of human behaviors from the perspective of "demand" [55].

In an unfamiliar environment, a student often urgently needs to build a close relationship with teachers and other students, facilitate heterosexual exchanges, and broaden interpersonal relationships under a premise of the basic realization of physiological needs and safety needs. Furthermore, the student will pursuit the realization of esteem needs and self-actualization, such as by enhancing their personal ability, increasing extra-curricular knowledge, and earning personal honor. Extending the scope of relationship and improving communication skills are important motivations for joining college organizations, and this has been confirmed by some qualitative analyses of the predecessors $[56,57]$. However, if the membership fails to realize their expected love and belonging needs, the student may choose to quit the organization.

\subsection{Exit Behavior Based on Expectancy Theory}

Expectancy theory, initiated by U.S. psychologist and behavioral scientist Victor H. Vroom, holds the view that people are always eager to meet certain requirements and try to achieve certain goals [58]. 
Until the goals are realized, it remains a motivation for an individual's actions. The power of motivation depends on the product of target value (valence) and expected probability (expectancy). In particular, effective guidance and training enable organization members to master some skills and improve their capacity to deal with issues in the organization. Definite, reasonable and effective promotion mechanisms are beneficial to stimulate enthusiasm of the members. Lack of effective motivations, such as training and promotion mechanisms, would lead members to quit the organization.

Therefore, based on the social cognition theory and Maslow's hierarchy of needs, we can build a framework to analyze the effects of influential factors on the involvement behavior (see the upper part of Figure 1).

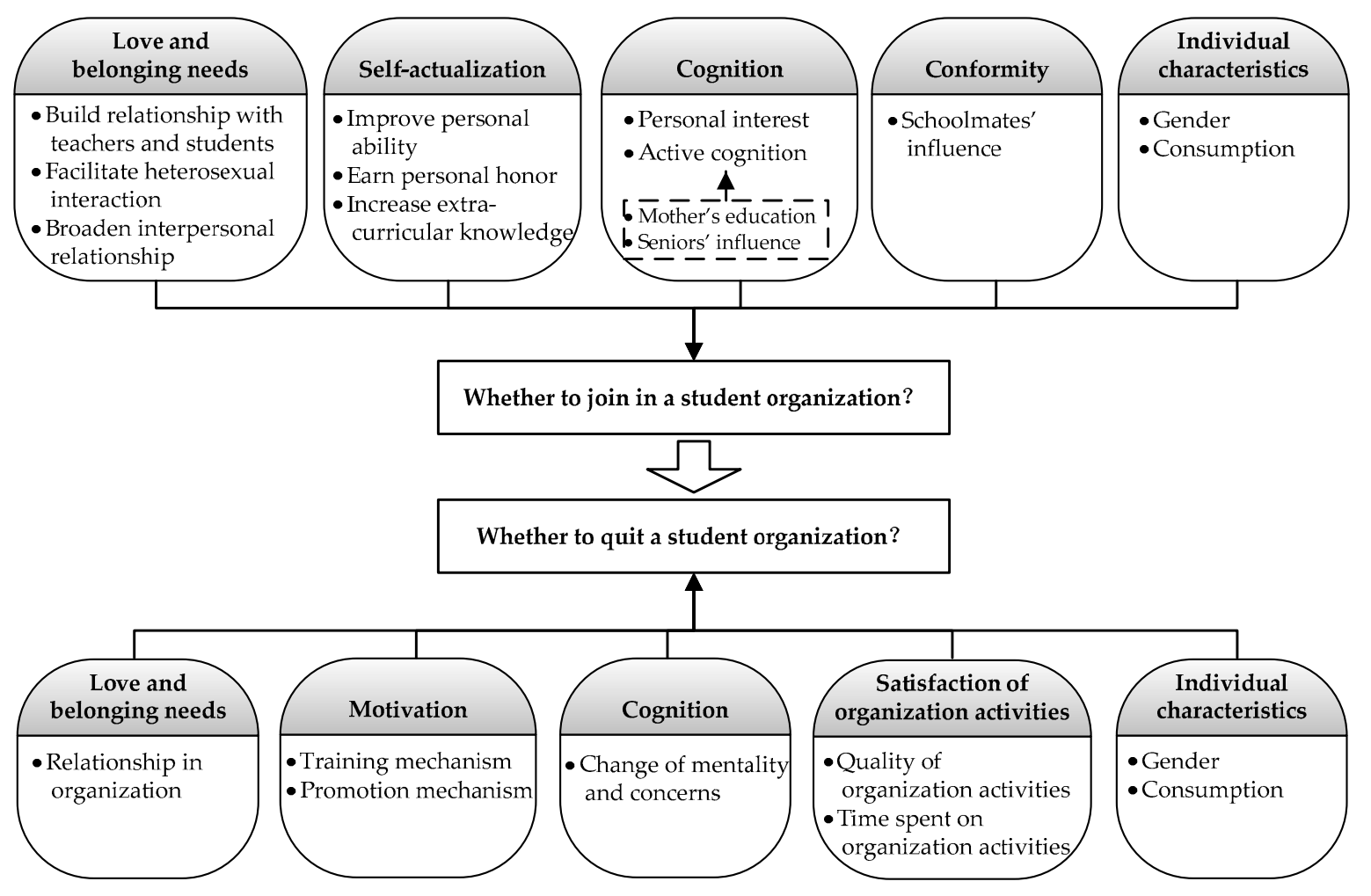

Figure 1. A conceptual framework of students' involvement and exit behaviors in college organizations.

Equation (1): University students' involvement behavior $=\mathrm{f}$ (love and belonging needs, self-actualization, cognition, conformity, individual characteristics $)=f($ build relationship with teachers and other students, facilitate heterosexual interaction, broaden interpersonal relations; improve personal ability, earn personal honor, increase extra-curricular knowledge; active cognition, personal interest; schoolmates' influence; gender, consumption).

Active cognition $=\mathrm{f}($ mother's education; seniors' influence).

Based on Maslow's hierarchy of needs and expectancy theory, we build a framework to analyze the effects of influential factors on the exit behavior (see the lower part of Figure 1).

Equation (2): University students' exit behavior $=\mathrm{f}$ (love and belonging needs, motivation, cognition, satisfaction of organization activities, individual characteristics) $=f($ relationship in organization; training mechanism, promotion mechanism; change of mentality and concerns; quality of organization activities, time spent on organization activities; gender, consumption). 


\section{Methodologies}

\subsection{Survey and Sampling}

The survey questionnaire contains questions about student organization involvement and exit behaviors, as well as socio-demographic inquiries. To improve representativeness, the survey was conducted in front of each canteen at Nanjing Agricultural University. Nanjing Agricultural University is a state-key university and is affiliated with the Chinese Ministry of Education. The university is supported by both the 985 Project of National Innovative Platform of Dominant Disciplines and the 211 Project, based on the advantages and characteristics of agriculture and life sciences, and has realized multi-disciplinary coordinated development in agriculture, sciences, economics, management, engineering, literature, and law. The school has 21 colleges (divisions), 61 undergraduate majors, and over 16,000 undergraduate students. According to the Wushulian 2017 Chinese University Ranking, Nanjing Agricultural University ranks 43rd in China and 6th in Jiangsu Province. As a comprehensive research university, from the perspective of professional set-up, student scale, and overall ranking, Nanjing Agricultural University is at an average level among the 116 key universities supported by the 211 Project. Therefore, Nanjing Agricultural University is a good representation of the best universities in China, and students from this university were selected as the research objects. Twenty-four undergraduate students from Nanjing Agricultural University administered the survey in January 2015, and the respondents included first, second, and third year undergraduate students. Due to graduation, employment, continuing study and other reasons, most senior students were not on campus, so excluding the seniors ensures sample randomness and overall representativeness. Adhering to a random sampling, this study used a face-to-face interview. Surveyors approached potential respondents for their participation. Each respondent who completed the survey was offered a $¥ 5$ gift. A total of 580 respondents were collected in the sample with 550 valid samples, and the valid return rate was $94.83 \%$.

\subsection{Analytical Procedures}

\subsubsection{The Involvement Behavior}

To investigate effects of the factors on students' involvement behavior, we adopted a conditional recursive mixed-process model (CMP), which is a type of systematic models. The CMP model was proposed by Roodman [59], who pointed out that several correlation models can be combined into a multi-equation system. Because the normal distribution has a natural multi-dimensional property, the residual terms have multivariate normal distributions in a system. Previous studies on the CMP were mainly focused on multistage procedures since they are more efficient in calculation with less statistics [59]. Nevertheless, the maximum likelihood estimation can estimate cumulative normal distribution curves with higher dimensions due to its fast calculation and effective simulation [59]. The CMP model can be expressed as follows:

$$
\left\{\begin{array}{c}
Y=\partial+\beta_{1 i} D_{1 i}+\beta_{2 j} D_{2 j}+\gamma_{m} K_{m}+\varphi C_{1}+\theta_{n} X_{n}+\mu \\
K_{1}=\omega Z_{1}+\tau Z_{2}+\varepsilon
\end{array}\right.
$$

In the first equation, the dependent variable $Y$ indicates whether the undergraduate participated in any student organizations ( 1 if participate, 0 otherwise). The independent variable matrix $D_{1 i}$ $(i=1,2,3)$ represents factors related to love and belonging needs, which are mainly measured from three aspects: building a good relationship with teachers and other students, facilitating heterosexual communication, and broadening interpersonal relations. The independent variable matrix $D_{2 j}(j=1$, $2,3)$ represents self-actualization factors. They are mainly measured from three aspects: Improving individual ability, increasing extra-curricular knowledge, and earning personal honor. In addition, the independent variable matrix $K_{m}(m=1,2)$ represents cognition factors. They are mainly measured 
by active cognition and personal interest. The independent variable $C_{1}$ represents conformity factors measured by schoolmates' influence. The independent variable $X_{n}(n=1,2,3)$ represents individual characteristics including gender, personal monthly consumption and its squared term. In the second equation, the independent variable $Z_{1}$ represents mother's education, and $Z_{2}$ represents seniors' influence. The variable definitions are presented in Table 1.

Table 1. Variable definition of the involvement behavior $(n=550)$.

\begin{tabular}{|c|c|c|c|c|c|c|}
\hline Variables & Description & Options & Mean & SD & Min & Max \\
\hline $\begin{array}{l}\text { Build } \\
\text { relationship }\end{array}$ & $\begin{array}{l}\text { Joining the organization can build a } \\
\text { good relationship with teachers and } \\
\text { other students }[30,36] .\end{array}$ & $\begin{array}{c}1=\text { completely disagree } \\
2=\text { disagree } \\
3=\text { neutral (unclear) } \\
4=\text { agree } \\
5=\text { completely agree }\end{array}$ & 2.615 & 0.737 & 1 & 5 \\
\hline $\begin{array}{l}\text { Facilitate } \\
\text { interaction }\end{array}$ & $\begin{array}{l}\text { Joining the organization is good for } \\
\text { heterosexual interactions. }\end{array}$ & $\begin{array}{c}1=\text { completely disagree } \\
2=\text { disagree } \\
3=\text { neutral (unclear) } \\
4=\text { agree } \\
5=\text { completely agree }\end{array}$ & 2.309 & 0.716 & 1 & 5 \\
\hline \multicolumn{7}{|c|}{ Self-actualization } \\
\hline $\begin{array}{l}\text { Improve } \\
\text { personal } \\
\text { ability }\end{array}$ & $\begin{array}{c}\text { Joining the organization helps improve } \\
\text { personal ability } \\
{[31,33,35,36,38-40,47,57]}\end{array}$ & $\begin{array}{c}1=\text { completely disagree } \\
2=\text { disagree } \\
3=\text { neutral (unclear) } \\
4=\text { agree } \\
5=\text { completely agree }\end{array}$ & 3.851 & 0.741 & 1 & 5 \\
\hline $\begin{array}{l}\text { Increase } \\
\text { extra-curricular } \\
\text { knowledge }\end{array}$ & $\begin{array}{c}\text { Joining the organization can increase } \\
\text { extra-curricular knowledge } \\
{[33,35,36,38-40,57] .}\end{array}$ & $\begin{array}{c}1=\text { completely disagree } \\
2=\text { disagree } \\
3=\text { neutral (unclear) } \\
4=\text { agree } \\
5=\text { completely agree }\end{array}$ & 3.753 & 0.757 & 1 & 5 \\
\hline \multicolumn{7}{|c|}{ Cognition } \\
\hline $\begin{array}{l}\text { Active } \\
\text { cognition }\end{array}$ & $\begin{array}{c}\text { Before joining the organization, do you } \\
\text { make an active cognition of } \\
\text { organization? [34] }\end{array}$ & $\begin{array}{c}1=\text { absolutely do not know } \\
2=\text { do not know } \\
3=\text { neutral (indifferent) } \\
4=\text { know } \\
5=\text { absolutely know }\end{array}$ & 3.247 & 0.776 & 1 & 5 \\
\hline $\begin{array}{l}\text { Personal } \\
\text { interest }\end{array}$ & $\begin{array}{l}\text { Before joining the organization, do you } \\
\text { have interest in it? }[30,31,33,38,39]\end{array}$ & $\begin{array}{c}1=\text { absolutely no interest } \\
2=\text { no interest } \\
3=\text { neutral (indifferent) } \\
4=\text { interested } \\
5=\text { strongly interested }\end{array}$ & 3.542 & 0.815 & 1 & 5 \\
\hline \multicolumn{7}{|c|}{ Conformity } \\
\hline $\begin{array}{l}\text { Schoolmates' } \\
\text { influence }\end{array}$ & $\begin{array}{c}\text { Whether schoolmates' decisions about } \\
\text { organization involvement influences } \\
\text { your decision? [31] }\end{array}$ & $\begin{array}{l}0=\text { no } \\
1=\text { yes }\end{array}$ & 0.642 & 0.480 & 0 & 1 \\
\hline \multicolumn{7}{|c|}{ Individual characteristics } \\
\hline Gender & & $\begin{array}{c}0=\text { female } \\
1=\text { male }\end{array}$ & 0.516 & 0.500 & 0 & 1 \\
\hline
\end{tabular}


Table 1. Cont.

\begin{tabular}{|c|c|c|c|c|c|c|}
\hline Variables & Description & Options & Mean & SD & Min & Max \\
\hline $\begin{array}{l}\text { Mother's } \\
\text { education }\end{array}$ & & $\begin{array}{c}1 \text { = primary school or below } \\
2 \text { = junior middle school } \\
3 \text { = senior high school or } \\
\text { secondary vocational school } \\
4=\text { college students } \\
5=\text { postgraduates }\end{array}$ & 2.403 & 1.045 & 1 & 5 \\
\hline $\begin{array}{l}\text { Seniors' } \\
\text { influence }\end{array}$ & $\begin{array}{l}\text { Whether the senior students' } \\
\text { introduction influences your decision? }\end{array}$ & $\begin{array}{l}0=\text { no } \\
1=\text { yes }\end{array}$ & 0.651 & 0.477 & 0 & 1 \\
\hline
\end{tabular}

\subsubsection{The Exit Behavior}

In a similar vein, a binary selection model is used to analyze the effects of factors on the exit behavior.

$$
\begin{aligned}
Y_{\text {exit }}=\partial+ & \rho D_{\text {out }}+\gamma_{j} M_{j}+\alpha K_{\text {out }}+\delta_{t} S_{t}+\theta_{k} X_{k}+\mu Y_{\text {exit }} \\
& =\partial+\rho D_{\text {out }}+\gamma_{j} M_{j}+\alpha K_{\text {out }}+\delta_{t} S_{t}+\theta_{k} X_{k}+\mu
\end{aligned}
$$

In the Equation (2), the dependent variable $Y$ indicates whether undergraduate students quit the organization activities ( 1 if quit, 0 otherwise). The exit behavior here not only means that the members submit a formal withdrawal application to the organization committee, but also includes the members that do not participate in the organization activities for more than one month and do not continue to participate, although their withdrawal applications have not been formally filed.

The independent variable $D_{\text {out }}$ represents love and belonging needs factors measured by relationships in organizations. $M_{j}(j=1,2)$ represents motivation factors measured by training and promotion mechanisms. $K_{\text {out }}$ represents cognition measured by the change in mentality and concerns. $S_{t}(t=1,2)$ represents the satisfaction of organization activities measured by the quality of organization activities and time spent on organization activities. $X_{k}(k=1,2,3)$ represents individual characteristics including gender, personal monthly consumption and consumption square. The variable definitions in the exit equation are presented in Table 2.

\begin{tabular}{|c|c|c|c|c|c|c|}
\hline Variables & Description & Options & Mean & SD & Min & $\operatorname{Max}$ \\
\hline $\begin{array}{l}\text { Organization } \\
\text { exit }\end{array}$ & Have you quit the organization & $\begin{array}{l}0=\text { no } \\
1=\text { yes }\end{array}$ & 0.390 & 0.488 & 0 & 1 \\
\hline \multicolumn{7}{|c|}{ Love and belonging needs } \\
\hline $\begin{array}{l}\text { Relationship } \\
\text { in } \\
\text { organization }\end{array}$ & $\begin{array}{l}\text { The organizations have distinct } \\
\text { hierarchy, interpersonal indifference and } \\
\text { low degrees of fusion }[34,35,40,60] \text {. }\end{array}$ & $\begin{array}{c}1=\text { completely disagree } \\
2=\text { disagree } \\
3=\text { neutral (unclear) } \\
4=\text { agree } \\
5=\text { completely agree }\end{array}$ & 2.757 & 0.971 & 1 & 5 \\
\hline \multicolumn{7}{|c|}{ Motivation } \\
\hline $\begin{array}{l}\text { Training } \\
\text { mechanism }\end{array}$ & $\begin{array}{l}\text { There are less training opportunities and } \\
\text { no effective guidance from teachers in } \\
\text { charge in organization }[33-35,39] .\end{array}$ & $\begin{array}{c}1=\text { completely disagree } \\
2=\text { disagree } \\
3=\text { neutral (unclear) } \\
4=\text { agree } \\
5=\text { completely agree }\end{array}$ & 3.070 & 0.854 & 1 & 5 \\
\hline $\begin{array}{l}\text { Promotion } \\
\text { mechanism }\end{array}$ & $\begin{array}{c}\text { The promotion mechanism of the } \\
\text { organization is not clear. Doing more or } \\
\text { less, doing well or bad are the same } \\
{[31,33,35] \text {. }}\end{array}$ & $\begin{array}{c}1=\text { completely disagree } \\
2=\text { disagree } \\
3=\text { neutral (unclear) } \\
4=\text { agree } \\
5=\text { completely agree }\end{array}$ & 3.520 & 0.639 & 2 & 5 \\
\hline
\end{tabular}

Table 2. Variable definition of the exit behavior $(n=444)$. 
Table 2. Cont.

\begin{tabular}{|c|c|c|c|c|c|c|}
\hline Variables & Description & Options & Mean & SD & Min & Max \\
\hline \multicolumn{7}{|c|}{ Cognition } \\
\hline $\begin{array}{l}\text { Change of } \\
\text { mentality } \\
\text { and concerns }\end{array}$ & $\begin{array}{l}\text { As the grade grows, the mentality and } \\
\text { concerns will change. }\end{array}$ & $\begin{array}{c}1=\text { completely disagree } \\
2=\text { disagree } \\
3=\text { neutral (unclear) } \\
4=\text { agree } \\
5=\text { completely agree }\end{array}$ & 3.279 & 0.923 & 1 & 5 \\
\hline \multicolumn{7}{|c|}{ Satisfaction of organization activities } \\
\hline $\begin{array}{l}\text { Quality of } \\
\text { activities }\end{array}$ & $\begin{array}{l}\text { The organization of activities is dull, and } \\
\text { the content of activities is old-fashioned } \\
\qquad[31,34,35,37,40,57] .\end{array}$ & $\begin{array}{c}1=\text { completely disagree } \\
2=\text { disagree } \\
3=\text { neutral (unclear) } \\
4=\text { agree } \\
5=\text { completely agree }\end{array}$ & 3.117 & 0.836 & 1 & 5 \\
\hline Waste time & $\begin{array}{l}\text { Organizing the activities wastes my time } \\
\text { and reduces the time for other learning } \\
\text { and part-time job }[31,33] \text {. }\end{array}$ & $\begin{array}{c}1=\text { completely disagree } \\
2=\text { disagree } \\
3=\text { neutral (unclear) } \\
4=\text { agree } \\
5=\text { completely agree }\end{array}$ & 3.140 & 0.933 & 1 & 5 \\
\hline \multicolumn{7}{|c|}{ Individual characteristics } \\
\hline Gender & & $\begin{array}{l}0=\text { female } \\
1=\text { male }\end{array}$ & 0.487 & 0.500 & 0 & 1 \\
\hline Consumption & Personal monthly consumption amount & & 1211 & 1016 & 100 & 15,000 \\
\hline
\end{tabular}

\section{Results}

\subsection{Descriptive Statistics}

A summary of the variables related to the involvement behavior is presented in Table 1 . The proportion of respondents who have participated in college organizations is $85.82 \%$. Regarding the factors, in general, love and belonging needs are the main factors that influence the respondents' involvement behavior. Before joining the organization, respondents who think that joining the organization can help build a close relationship with teachers and other students (agree and completely agree) account for $43.27 \%$. Respondents who agree that joining the organization can facilitate heterosexual communication account for $64 \%$. The percentage of respondents who agree that joining the organization helps broaden interpersonal relations is $88.73 \%$. Secondly, regarding the need for self-actualization, the percentage of respondents who agree that joining the organization helps enhance personal ability of the respondent is $77.81 \%$. The respondents who agree that joining the organization can increase extra-curricular knowledge take $75.27 \%$. The percentage of respondents who agree that joining the organization can earn personal honor for the respondent is $42.55 \%$.

In addition, for the cognition factors, respondents who make an active cognition of organizations account for $38.18 \%$; the percentage of respondents who choose the organization because of being interested in it is 56.73\%. Furthermore, respondents who think the schoolmates' decisions about organization involvement influence themselves account for $64.23 \%$.

Information on the socio-demographics of the sampled undergraduate students and their respective proportions is also presented in Table 1. Male respondents account for $51.64 \%$. The average personal monthly consumption is 1210 Yuan and the consumption between 500 and 1500 Yuan accounts for more than $90 \%$. The respondents whose mother held a college or higher degree account for $17.95 \%$. The respondents who think that the senior students' introduction influence their decisions are $65.09 \%$.

A summary of the variables related to the exit behavior is presented in Table 2. In the survey, the percentage of respondents who have ever quit a college organization is $39.01 \%$. Firstly, respondents who think the organizations have a distinct hierarchy, interpersonal indifference and low degrees of fusion (agree and completely agree) account for $24.77 \%$. The percentage of respondents who agree that the organization lacks training mechanisms is $28.82 \%$, and the percentage of respondents who agree that the organization lacks promotion mechanisms is $39.19 \%$. Both motivation factors dampen 
the enthusiasm of organization members. Respondents who agree that the mentality and concerns change as the grade grows account for $50.45 \%$. Moreover, the percentage of respondents who think that the activities of organization are dull and the content of activities is old-fashioned is $32.88 \%$. The respondents who think that organizing activities waste a lot of time and reduce the time for their own learning and part-time jobs are33.79\%. These two issues reduce their participation satisfaction.

The results of pairwise tests are presented in Tables 3 and 4 . The involvement group has a greater value in broadening interpersonal relations, improving personal ability, increasing extra-curricular knowledge, earning personal honor, active cognition, personal interest, schoolmates' influence, while a smaller value in building relationship and gender. The exit group has a greater value in the relationship in organization, training mechanisms, promotion mechanisms, change of mentality and concerns, quality of activities, and wasting time. Though the pairwise comparison is helpful, the regression results provide more insights on the effects of certain variables while holding others constant.

Table 3. Comparison between involvement and non-involvement groups.

\begin{tabular}{|c|c|c|c|}
\hline Variables & Involvement $(\mathrm{N}=472)$ & Non-Involvement $(\mathbf{N}=78)$ & Mean Diff \\
\hline \multicolumn{4}{|l|}{ Love and belonging needs } \\
\hline Build relationship & 2.590 & 2.770 & $-0.180^{* *}$ \\
\hline Facilitate interaction & 2.330 & 2.210 & 0.120 \\
\hline Broaden interpersonal relations & 4.160 & 3.560 & $0.600^{* * *}$ \\
\hline \multicolumn{4}{|l|}{ Self-actualization } \\
\hline Improve personal ability & 3.950 & 3.230 & $0.720 * * *$ \\
\hline Increase extra-curricular knowledge & 3.840 & 3.210 & $0.640 * * *$ \\
\hline Earn personal honor & 3.380 & 3.080 & $0.300 * * *$ \\
\hline \multicolumn{4}{|l|}{ Cognition } \\
\hline Active cognition & 3.380 & 2.440 & $0.950 * * *$ \\
\hline Personal interest & 3.710 & 2.540 & $1.170^{* * *}$ \\
\hline \multicolumn{4}{|l|}{ Conformity } \\
\hline Schoolmates' influence & 0.690 & 0.360 & $0.330 * * *$ \\
\hline \multicolumn{4}{|l|}{ Individual characteristics } \\
\hline Gender & 0.470 & 0.790 & $-0.320 * * *$ \\
\hline Consumption & 1210 & 1212 & -1.750 \\
\hline
\end{tabular}

Table 4. Comparison between exit and non-exit groups.

\begin{tabular}{|c|c|c|c|}
\hline Variables & Exit $(\mathrm{N}=174)$ & Non-Exit $(\mathrm{N}=270)$ & Mean Diff \\
\hline \multicolumn{4}{|l|}{ Love and belonging needs } \\
\hline Relationship in organization & 2.970 & 2.620 & $0.340^{* * *}$ \\
\hline \multicolumn{4}{|l|}{ Motivation } \\
\hline Training mechanism & 3.250 & 2.960 & $0.290^{* * *}$ \\
\hline Promotion mechanism & 3.930 & 3.260 & $0.680^{* * *}$ \\
\hline \multicolumn{4}{|l|}{ Cognition } \\
\hline $\begin{array}{l}\text { Change of mentality and } \\
\text { concerns }\end{array}$ & 3.550 & 3.100 & $0.450 * * *$ \\
\hline \multicolumn{4}{|l|}{$\begin{array}{l}\text { Satisfaction of organization } \\
\text { activities }\end{array}$} \\
\hline Quality of activities & 3.240 & 3.040 & $0.200 * *$ \\
\hline Waste time & 3.250 & 3.070 & $0.190 * *$ \\
\hline \multicolumn{4}{|l|}{ Individual characteristics } \\
\hline Gender & 0.470 & 0.500 & -0.030 \\
\hline Consumption & 1178 & 1232 & -54.080 \\
\hline
\end{tabular}




\subsection{Estimation Results of the Involvement Behavior}

The results of the organization involvement behavior are presented in Table 5. The results from the CMP model show that there is a significant correlation between the probit model and CMP model (Atanhrho_12 is significant). So the CMP is more efficient, and the estimated coefficients of the critical variables, such as building relationship, facilitating interactions, broadening interpersonal relations, active cognition and personal interest are obviously underestimated in the ordered probit model. Therefore, the following interpretation is focused on the results from the CMP model.

Table 5. The estimated results and conditional marginal effects of organization involvement behavior model.

\begin{tabular}{|c|c|c|c|c|}
\hline \multirow{2}{*}{ Variables } & \multicolumn{2}{|c|}{ Probit Model } & \multicolumn{2}{|c|}{ CMP Model } \\
\hline & Coefficient & Marginal Effect & Coefficient & Marginal Effect \\
\hline \multicolumn{5}{|l|}{ The first equation } \\
\hline \multicolumn{5}{|l|}{ Love and belonging needs } \\
\hline Build relationship & $\begin{array}{c}0.408^{* * *} \\
(0.137)\end{array}$ & $\begin{array}{c}0.034^{* *} \\
(0.013)\end{array}$ & $\begin{array}{c}0.276 \text { ** } \\
(0.114)\end{array}$ & $\begin{array}{c}0.047^{* * *} \\
(0.018)\end{array}$ \\
\hline Facilitate interaction & $\begin{array}{c}0.897 * * * \\
(0.141)\end{array}$ & $\begin{array}{c}0.076^{* * *} \\
(0.019)\end{array}$ & $\begin{array}{c}0.670 * * * \\
(0.131)\end{array}$ & $\begin{array}{l}0.114^{* * *} \\
(0.023)\end{array}$ \\
\hline $\begin{array}{l}\text { Broaden interpersonal } \\
\text { relations }\end{array}$ & $\begin{array}{l}0.362 * * \\
(0.160)\end{array}$ & $\begin{array}{l}0.031 * \\
(0.015)\end{array}$ & $\begin{array}{l}0.259 * \\
(0.135) \\
\end{array}$ & $\begin{array}{l}0.045^{*} \\
(0.023)\end{array}$ \\
\hline \multicolumn{5}{|l|}{ Self-actualization } \\
\hline Improve personal ability & $\begin{array}{c}0.173 \\
(0.140)\end{array}$ & $\begin{array}{c}0.014 \\
(0.011)\end{array}$ & $\begin{array}{c}0.120 \\
(0.111)\end{array}$ & $\begin{array}{c}0.019 \\
(0.017)\end{array}$ \\
\hline $\begin{array}{l}\text { Increase extra-curricular } \\
\text { knowledge }\end{array}$ & $\begin{array}{c}0.171 \\
(0.141) \\
\end{array}$ & $\begin{array}{c}0.015 \\
(0.013) \\
\end{array}$ & $\begin{array}{c}0.061 \\
(0.105) \\
\end{array}$ & $\begin{array}{c}0.011 \\
(0.018) \\
\end{array}$ \\
\hline Earn personal honor & $\begin{array}{c}0.200 \\
(0.143)\end{array}$ & $\begin{array}{c}0.017 \\
(0.011)\end{array}$ & $\begin{array}{c}0.167 \\
(0.108)\end{array}$ & $\begin{array}{l}0.028^{*} \\
(0.016)\end{array}$ \\
\hline \multicolumn{5}{|l|}{ Cognition } \\
\hline Active cognition & $\begin{array}{c}0.720 * * * \\
(0.143)\end{array}$ & $\begin{array}{l}0.06^{* * *} \\
(0.015)\end{array}$ & $\begin{array}{l}1.410 * * * \\
(0.134)\end{array}$ & $\begin{array}{c}0.236 \text { *** } \\
(0.066)\end{array}$ \\
\hline Personal interest & $\begin{array}{l}0.937 * * * \\
(0.173)\end{array}$ & $\begin{array}{l}0.079 * * * \\
(0.015)\end{array}$ & $\begin{array}{c}0.703 * * * \\
(0.155)\end{array}$ & $\begin{array}{l}0.120 * * * \\
(0.020)\end{array}$ \\
\hline \multicolumn{5}{|l|}{ Conformity } \\
\hline Schoolmate' influence & $\begin{array}{c}0.152 \\
(0.171)\end{array}$ & $\begin{array}{c}0.013 \\
(0.014)\end{array}$ & $\begin{array}{l}-0.056 \\
(0.135)\end{array}$ & $\begin{array}{l}-0.009 \\
(0.023)\end{array}$ \\
\hline \multicolumn{5}{|l|}{ Individual characteristics } \\
\hline Gender & $\begin{array}{c}-0.454^{* *} \\
(0.188)\end{array}$ & $\begin{array}{c}-0.038^{* *} \\
(0.018)\end{array}$ & $\begin{array}{l}-0.164 \\
(0.147)\end{array}$ & $\begin{array}{l}-0.027 \\
(0.024)\end{array}$ \\
\hline Consumption & $\begin{array}{l}-3.32 \times 10^{-5} \\
\left(2.12 \times 10^{-4}\right)\end{array}$ & $\begin{array}{l}-2.80 \times 10^{-6} \\
\left(1.77 \times 10^{-5}\right)\end{array}$ & $\begin{array}{c}-0.899 \times 10^{-5} \\
\left(1.50 \times 10^{-4}\right)\end{array}$ & $\begin{array}{l}-1.52 \times 10^{-5} \\
\left(2.52 \times 10^{-5}\right)\end{array}$ \\
\hline Consumption_sq & $\begin{array}{l}-4.93 \times 10^{-9} \\
\left(3.29 \times 10^{-9}\right)\end{array}$ & $\begin{array}{c}-2.21 \times 10^{-10} \\
\left(1.15 \times 10^{-9}\right)\end{array}$ & $\begin{array}{c}1.23 \times 10^{-9} \\
\left(9.70 \times 10^{-9}\right)\end{array}$ & $\begin{array}{l}2.11 \times 10^{-10} \\
\left(1.65 \times 10^{-9}\right)\end{array}$ \\
\hline Constant & $\begin{array}{c}-10.304^{* * *} \\
(1.457)\end{array}$ & & $\begin{array}{c}-10.24^{* * *} \\
(1.293)\end{array}$ & \\
\hline \multicolumn{5}{|l|}{ The second equation } \\
\hline Mother's education & & & $\begin{array}{c}0.222 * * * \\
(0.047)\end{array}$ & \\
\hline Seniors' influence & & & $\begin{array}{c}0.897^{* * *} \\
(0.099)\end{array}$ & \\
\hline
\end{tabular}


Table 5. Cont.

\begin{tabular}{|c|c|c|c|c|}
\hline \multirow{2}{*}{ Variables } & \multicolumn{2}{|c|}{ Probit Model } & \multicolumn{2}{|c|}{ CMP Model } \\
\hline & Coefficient & Marginal Effect & Coefficient & Marginal Effect \\
\hline cut_2_1 & & & $\begin{array}{c}-0.866^{* * * *} \\
(0.158)\end{array}$ & \\
\hline cut_2_2 & & & $\begin{array}{l}-0.179 \\
(0.141)\end{array}$ & \\
\hline cut_2_3 & & & $\begin{array}{c}1.446^{* * *} \\
(0.157)\end{array}$ & \\
\hline cut_2_4 & & & $\begin{array}{c}3.420 * * * \\
(0.202)\end{array}$ & \\
\hline atanhrho_12 & & & $\begin{array}{c}-1.080^{* * * *} \\
(0.236)\end{array}$ & \\
\hline Wald chi2(12) & $112.61^{* * *}$ & & $407.33^{* * *}$ & \\
\hline
\end{tabular}

Notes: Robust standard errors in parentheses. ${ }^{* * *} p<0.01,{ }^{* *} p<0.05,{ }^{*} p<0.10$.

From the perspective of love and belonging needs, the estimated coefficients of building relationship and facilitating interaction are positive and significant $(p<0.05$ and $p<0.01$, respectively). The results indicate that respondents who agree that joining the organizations can bring a closer relationship with teachers and other students, and promote heterosexual exchanges, are more likely to join the organizations. This is in alignment with the theoretical analysis. From the perspective of cognition, the estimated coefficients of active cognition and personal interest are positive and significant $(p<0.01)$. The results are in line with the hypothesis. With a deeper understanding of and being more interested in the organizations, the respondents are more likely to join. Furthermore, the estimated coefficients of mother's education and seniors' influence are positive and significant $(p<0.01)$. The results indicate that students whose mother has a higher education level show a stronger intention to participate in the organizations, and students often refer to the seniors' advices when making choices about organization participation.

In addition, the marginal effects of building relationship, facilitating interaction, active cognition, and personal interest are $0.047,0.114,0.236$ and 0.120 (see Table 5), respectively. The marginal effect of active cognition means for one unit increase in active cognition, the participation rate increases by $23.6 \%$. This indicates that active cognition is the most critical factor, followed by personal interest and facilitating interaction, while the effect of building relationships is the smallest. Additionally, the marginal effects of mother's education (see Table 6) are $-0.012,-0.026,-0.046,0.077$, and 0.006, while the marginal effects of seniors' influence are $-0.050,-0.104,-0.185,0.314$, and 0.025 , when the values of how to influence students' cognition are equal to 1, 2, 3, 4, and 5, respectively, and all of them are significant $(p<0.01)$. It indicates each level of increase in mother's education or senior students' influence leads to a decrease in the probability of students' cognition about "absolutely do not know", "relatively do not know" and "neutral", while an increase in the probability of students' cognition about "relatively know" and "urgent know". A comparison shows the senior students' influence has a higher positive effect than mother's education.

Table 6. Conditional marginal effects of active cognition, based on the estimated results of the second equation in the CMP model for organization involvement behavior.

\begin{tabular}{cccccc}
\hline Variable & $\begin{array}{c}\text { Active } \\
\text { Cognition }=\mathbf{1}\end{array}$ & $\begin{array}{c}\text { Active } \\
\text { Cognition }=\mathbf{2}\end{array}$ & $\begin{array}{c}\text { Active } \\
\text { Cognition }=\mathbf{3}\end{array}$ & $\begin{array}{c}\text { Active } \\
\text { Cognition }=\mathbf{4}\end{array}$ & $\begin{array}{c}\text { Active } \\
\text { Cognition }=\mathbf{5}\end{array}$ \\
\hline Mother's & $-0.012^{* * *}$ & $-0.026^{* * *}$ & $-0.046^{* * *}$ & $0.077^{* * *}$ & $0.006^{* * *}$ \\
education & $(0.003)$ & $(0.006)$ & $(0.011)$ & $(0.017)$ & $(0.002)$ \\
\hline Seniors' & $-0.050^{* * *}$ & $-0.104^{* * *}$ & $-0.185^{* * *}$ & $0.314^{* * *}$ & $0.025^{* * *}$ \\
influence & $(0.011)$ & $(0.152)$ & $(0.029)$ & $(0.035)$ & $(0.002)$ \\
\hline
\end{tabular}

Notes: Standard errors in parentheses. ${ }^{* * *} p<0.01$. 


\subsection{Estimation Results of the Exit Behavior}

The estimation results about the organization exit behavior are presented in Table 7. From the perspective of love and belonging needs, the estimated coefficients of relationship in an organization are positive and significant $(p<0.01)$. It indicates that after joining the organizations, the complicated interpersonal relationships and bureaucratic style may cause some members to quit. This is in alignment with the theoretical analysis. For motivation, the coefficients of training mechanisms and promotion mechanisms are positive and significant $(p<0.01)$. The results are in line with the hypothesis that the less training opportunities, less guidance from professional teachers, and unclear promotion mechanisms, the more likely the members quit. In terms of cognation, the estimated coefficients of mentality change is significantly positive. This indicates that along with increasing grade and changing psychology, the cognition of respondents changes and they are more likely to quit the organizations. From the perspective of satisfaction of organization activities, the estimated coefficients of activity quality and wasting time are positive. The results indicate that the less satisfied for the activity quality and more time spending with the organization, the more likely that the members quit.

Table 7. The estimated results and conditional marginal effects of organization exit behavior using the probit model.

\begin{tabular}{|c|c|c|}
\hline Variables & Coefficient & Marginal Effect \\
\hline \multicolumn{3}{|l|}{ Love and belonging needs } \\
\hline Relationship in organization & $\begin{array}{c}0.454^{* * *} \\
(0.108)\end{array}$ & $\begin{array}{c}0.141^{* * *} \\
(0.036)\end{array}$ \\
\hline \multicolumn{3}{|l|}{ Motivation } \\
\hline Training mechanism & $\begin{array}{c}0.530 * * * \\
(0.144)\end{array}$ & $\begin{array}{c}0.165^{* * *} \\
(0.047)\end{array}$ \\
\hline Promotion mechanism & $\begin{array}{c}1.869^{* * *} \\
(0.265)\end{array}$ & $\begin{array}{c}0.583^{* * *} \\
(0.104)\end{array}$ \\
\hline \multicolumn{3}{|l|}{ Cognition } \\
\hline Change in mentality and concerns & $\begin{array}{c}0.278^{* * *} \\
(0.093)\end{array}$ & $\begin{array}{c}0.087^{* * *} \\
(0.029)\end{array}$ \\
\hline \multicolumn{3}{|l|}{ Satisfaction of organization activities } \\
\hline Quality of activities & $\begin{array}{c}0.623^{* * *} \\
(0.150)\end{array}$ & $\begin{array}{c}0.194^{* * *} \\
(0.050)\end{array}$ \\
\hline Waste time & $\begin{array}{c}0.387^{* * *} \\
(0.130)\end{array}$ & $\begin{array}{c}0.120^{* * *} \\
(0.043)\end{array}$ \\
\hline \multicolumn{3}{|l|}{ Individual characteristics } \\
\hline Gender & $\begin{array}{c}0.019 \\
(0.155) \\
\end{array}$ & $\begin{array}{c}0.006 \\
(0.048)\end{array}$ \\
\hline Consumption & $\begin{array}{c}0.001 \\
(0.001)\end{array}$ & $\begin{array}{c}2.55 \times 10^{-4} \\
\left(1.68 \times 10^{-4}\right)\end{array}$ \\
\hline Consumption_sq & $\begin{array}{l}-2.39 \times 10^{-7} \\
\left(3.15 \times 10^{-9}\right)\end{array}$ & $\begin{array}{l}-7.47 \times 10^{-8} \\
\left(5.57 \times 10^{-8}\right)\end{array}$ \\
\hline Constant & $\begin{array}{c}14.621^{* * *} \\
(1.814)\end{array}$ & \\
\hline Wald chi2 $(\mathrm{df}=9)$ & $85.89^{* * *}$ & \\
\hline
\end{tabular}

Notes: Standard errors in parentheses. ${ }^{* * *} p<0.01$.

Furthermore, the marginal effects of relationship in organization, training mechanism, promotion mechanism, change in mentality and concerns, quality of activities, and waste time are $0.141,0.165$, $0.583,0.087,0.194$, and 0.120 (see Table 7), respectively. It indicates the most influential factor is the 
unclear promotion mechanism, followed by quality of activities, training mechanism, relationship in organization, wasting time, and mentality change.

\section{Discussion}

Based on the social cognition theory, Maslow's hierarchy of needs, and expectancy theory, this study examines the factors influencing students' involvement and exit behaviors in college organizations using a conditional recursive mixed-process model and a probit model. We provide insights on strategies on sustainable management of college organizations as well as to prevent large-scale exit behaviors. The implications are beneficial to achieving ideological and political sustainability in higher education through college student organizations.

The survey results show the respondents who have participated in college organizations account for $85.82 \%$, and those who quit account for $39.01 \%$.In general, the involvement behavior of student organizations is affected by the factors relating to love and belonging needs, cognition, while the organization exit behavior is affected by the factors relating to love and belonging needs, motivation, cognition and satisfaction of organization activities, but magnitudes of the effects vary. It is worth noting that monthly consumption has almost no significant influence on the exit behavior. Unlike the undergraduates in the United States, most Chinese undergraduates do not need to do a part-time job since all of the costs including tuition and living expenses are paid by their parents. So they have more time for other activities.

For the involvement behavior of student organizations, active cognition is most influential, followed by personal interest. With a deeper understanding of and being more interested in the organizations, the respondents are more likely to join [25]. Lack of information hinders students from joining organizations, while information acquisition can change their priori probability so that they can make a better decision [61]. Meanwhile, active cognition is affected by seniors' influence and mother's education, and the senior students' influence has a greater effect than mother's education. With the Fellow Townsmen Associationsat province-, prefecture- and country-levels, the senior fellows would give more reliable advices about student organizations. Meanwhile, workshops in each college can provide freshmen with personal experiences related to study and organizations from the sophomore, junior or even senior students.

In addition, the love and belonging needs is the second influential factor; the third important one is facilitating interactions; the effect of building relationship is the lowest. The more the respondents agree that joining organizations can bring a closer relationship with teachers and other students as well as promote heterosexual exchanges, the more likely they are to join the organizations. Firstly, it is very important to deal well with the relationship between college staff and students. For instance, scores from the class adviser accounts for about 35\% of the total score in the annual comprehensive assessment of college students in October2018. The class adviser also plays an important role in the annual application of scholarship, while the counselors have a positive effect on the application of provincial and school-level awards, including outstanding student leaders, outstanding student pacesetter cadres and outstanding Youth League cadres, and so on. Secondly, most students, especially those who are shy, hope to improve their interpersonal skills by participating in student organizations, to overcome their nervousness in formal situations. Thirdly, for the vast majority of college students in China, passing the college entrance examination is the only way to continue their studies (and have a bright future). As under the control of both parents and teachers, the students with excellent grades used to devote almost all of their energy and time to studying in their junior and senior high schools. For instance, they got up around 6 am, kept studying until 10 or 11 pm every day, and only had half day off every week. Therefore, these new undergraduates, about 18 years old and yearn for love, hope to increase the chance of heterosexual communication through student organizations and other activities. Compared with love and belonging needs, the freshmen consider self-actualization less, which is consistent with Maslow's hierarchy of needs. Freshmen urgently want to build a close teacher-student relation, affection, and friendship in their environments. Additionally, the insignificant effect of 
schoolmates' influence reflects the individual choices are not affected by schoolmates' decisions on organization involvement. Students tend to be more rational in choosing which organizations to join and no longer follow the trend blindly.

In terms of the exit behavior of student organizations, the most influential factor is the unclear promotion mechanisms of organizations. The expectancy theory suggests that lack of promotion mechanisms dampens the enthusiasm of organization members. Brennan [19] also indicated that universities should enable undergraduates to acquire the sustainable competences at the personal level. For instance, an emphasis should be given to the leadership capacity of students $[20,23,25,45]$. Thus, unclear promotion mechanisms may lead to the loss of talented organization managers, which hinders the achievement of organizational goals and the advancement of organizational core competence. Thus, identifying promotion mechanisms is one of characteristics of sustainable learning and change in student organizations from the perspective of organizational culture. The second important factor is high-quality activities. The less satisfied the organization members are, the more likely that they will quit. The survey show about $33 \%$ of the respondents agree that the activities are organized in a single form and their contents are old-fashioned, which make it difficult to attract widespread attention.

In fact, high-quality activities can help foster morally sound values and outlook on the world and life [36]. Some activities can help construct learning style and campus culture [7], such as a "Campus Cultural And Art Festival." Some activities should be considered an important approach for the sustainable development of ideological and political education $[7,32,38]$, such as "The Activities of League Day" and "The Activities of Party Day." By participating in these activities, students can make right decisions with unidentified information from the Internet. Some activities such as "social service" can equip undergraduates with competences for sustainable development related to responsibility and emotional intelligence [32,38]. As a result, regarding sustainability issues, undergraduates will have a positive attitude rather than displacing the responsibility to other people or organizations [1,2]. Some other activities can improve students preparedness for future jobs and help develop professional values $[22,33,38,39,47]$, such as a "Challenge Cup Business Plan Competition" and "National College Students' Science and Technology Innovation Project." Activities, such as an "Ethnic Culture Show" and "Traditional Culture Festival", can increase cross-racial interactions, since China has 56 nationalities with obvious differences in traditional cultures and habits. Therefore, on the one hand, from the perspective of organizational goals, sustainable student organizations should set dynamic development goals for sustainability. They should comprehensively consider dynamic social and business environments, and help tackle complex practical problems faced by students, while combining the nature and characteristics of student organizations themselves. It will benefit the organizations to successfully hold distinctive activities. On the other hand, from the perspective of organizational activities, under the background of "Internet+" and "Big Data", sustainable student organizations should make full use of information technology and relevant materials. Based on the double strategies of "bringing-in" and "going global," they should strengthen external publicity and communication, and draw on the successful development experience of excellent student organizations at home and abroad. This will help promote sustainable organizational learning and change, and continuously increase the core competence of these organizations.

Other factors include training mechanisms, personal relations in the organization, and wasting time. The less training opportunities and less guidance from professional teachers, the more likely that the members will quit. Student organizations should enable undergraduates to acquire skills at professional levels, which is similar to the findings of Brennan [19]. From the perspective of organizational culture, other characteristics of sustainable learning and change in student organizations are to develop professional knowledge and provide skills training. Take the "Student-Reporters Organization" as an example, famous journalists are invited to explain how to find clues to capture the news and news writing skills; photographers are invited to explain the skills to improve the level of photography, and what should be paid attention to in different occasions. In addition, after joining the organizations, the complicated interpersonal relations and bureaucratic style may lead some 
members to quit. As shown in the survey, about $24.77 \%$ of respondents said that it was difficult to adapt themselves to the internal environment of the organizations because of the complicated interpersonal relationships and bureaucracy. The China Youth Daily publishes a long report entitled "Bureaucratic style in college students organizations" criticizing the bureaucracy phenomenon in college organizations [62]. Recently, a commentary article entitled "College student cadres: are to act the high and mighty official or serve students" in Guangming Daily also disclosed the bureaucratic problems of student organizations [63]. Thus, whether individuals quit the organizations or not hinges on related regulations and organization management. Additionally, the effect of change in mentality and concerns is the lowest. A large number of activities take the members' time that they can spend on coursework and other academic activities. Along with increasing grades and the changing of psychology, the cognition of respondents changes and they are more likely to quit the organizations. Freshmen attach more importance to the improvement of communication competence and the realization of hobbies and interests. From the second year, the professional direction of students gradually becomes clear, and they begin to plan for their careers. As a result, their attention gradually shifts from organization activities to academic careers, and their enthusiasm towards participating in organizations weakens [64].

\section{Conclusions}

In summary, this paper contributes to behavioral and sustainability literature on students' involvement and exit of college organizations. A reasoning mechanism is developed to integrate the love and belonging needs, self-actualization, cognition, motivation, and satisfaction of organization activities to benefit organizational learning. Furthermore, a very representative school, Nanjing Agricultural University, is taken as the analysis object. Therefore, this research provide insights for analyzing the college students' involvement and exit behaviors towards organizational sustainability at other universities and colleges in China.

The management departments of student organizations may be pleased to know how these factors affect students' behaviors. The lessons learned here can enhance the effectiveness of organization leadership selection and prevent large-scale exits. This not only helps enrich the "second classroom" of undergraduates, but also enhances the effects of sustainable development of ideological and political education. Hence, the most important task is to organize professional teachers and experienced senior students to provide advices on organization selection and participation, as well as help freshmen plan their college life. Furthermore, harmonious interpersonal relations should be built within organizations to stimulate a strong sense of belonging and inspire strong motivations for organization activities. The incentive mechanisms should be improved and various incentive measures should be designed to stimulate students' enthusiasm for organization activities. Students should be encouraged to co-manage the organizations and provide suggestions on organization activities to improve their quality. In addition, to enhance membership recruitment and retention efforts, educators should focus their efforts on experiential activities that enable student-faculty contacts, career exploration, and skill development.

There are opportunities for some future research. Although it is of great significance to improve augmented management strategies, the leaders and management department of student organizations should emphasize future improvements, for example, to the selection process of organization leaders. It is no doubt that the leader competence can make a big difference for the sustainable development of organizations. In addition, sustainable management strategies need to be strengthened accordingly while considering the specific college student characteristics and student organizations at different universities.

Author Contributions: The study is the result of full collaboration and therefore the authors accept full responsibility. The Sections 1-3 are attributable to Q.Z.; the Section 4 is attributable to Y.F.; the Sections 5 and 6 are attributable to M.Z. and he is the corresponding author of the paper. All authors have read and approved the final manuscript. 
Funding: This project was funded by the National Natural Science Foundation of China (No. 71603129), the General Project of Philosophy and Social Sciences at Universities in Jiangsu (2016SJD880005), and the Humanities and Social Sciences Research Foundation of Central Universities at Nanjing Agricultural University (SKPT2016030; SKYC2018004).

Acknowledgments: We are grateful to the journal editor and two anonymous reviewers for their time and helpful comments to improve the paper.

Conflicts of Interest: The authors declare no conflict of interest.

\section{References and Notes}

1. Chaplin, G.; Wyton, P. Student engagement with sustainability: Understanding the value-action gap. Int. J. Sustain. High. Educ. 2014, 15, 404-417. [CrossRef]

2. Eagle, L.; Low, D.; Case, P.; Vandommele, L. Attitudes of undergraduate business students toward sustainability issues. Int. J. Sustain. High. Educ. 2015, 16, 650-668. [CrossRef]

3. Lambrechts, W.; Paul, W.T.; Jacques, A.; Walravens, H.; Van Liedekerke, L.; Van Petegem, P. Sustainability segmentation of business students: Toward self-regulated development of critical and interpretational competences in a post-truth era. J. Clean. Prod. 2018, 202, 561-570. [CrossRef]

4. Salvioni, D.M.; Franzoni, S.; Cassano, R. Sustainability in the higher education system: An opportunity to improve quality and image. Sustainability 2017, 9, 914. [CrossRef]

5. Waas, T.; Huge, J.; Ceulemans, K.; Lambrechts, W.; Vandenabeele, J.; Lozano, R.; Wright, T. Sustainable Higher Education. Understanding and Moving Forward; Instituut voor Milieu \& Duurzame Ontwikkeling, Antwerpen: Brussels, Belgium, 2012.

6. Different from students' unions, students organizations are defined as cultural, art, and academic groups composed of voluntary members. Regardless of grade, department or even school boundaries, students with similar interests come together to join the organizations. While students' unions are mass organizations under the guidance of school Party committee and Youth League committee, which link the students to the departments or school. The work basis of students' unions is around students and student representatives for benefits, to serve the students and promote the overall development of all students.

7. Yu, W.; Han, L.Y. Foreign Education Research; Jilin Press: Changchun, China, 2002.

8. Wals, A.E. Learning our way to sustainability. J. Educ. Sustain. Dev. 2011, 5, 177-186. [CrossRef]

9. Smith, P.A. The importance of organizational learning for organizational sustainability. Learn. Organ. 2012, 19, 4-10. [CrossRef]

10. Lambrechts, W.; Mulà, I.; Ceulemans, K.; Molderez, I.; Gaeremynck, V. The integration of competences for sustainable development in higher education: An analysis of bachelor programs in management. J. Clean. Prod. 2013, 48, 65-73. [CrossRef]

11. Filho, W.L.; Manolas, E.; Pace, P. The future we want: Key issues on sustainable development in higher education after Rio and the UN decade of education for sustainable development. Int. J. Sustain. High. Educ. 2015, 16, 112-129. [CrossRef]

12. Karatzoglou, B. An in-depth literature review of the evolving roles and contributions of universities to Education for Sustainable Development. J. Clean. Prod. 2013, 49, 44-53. [CrossRef]

13. Lozano, R.; Ceulemans, K.; Alonso-Almeida, M.; Huisingh, D.; Lozano, F.J.; Waas, T.; Lambrechts, W.; Lukman, R.; Hugé, J. A review of commitment and implementation of sustainable development in higher education: Results from a worldwide survey. J. Clean. Prod. 2015, 108, 1-18. [CrossRef]

14. Lozano, R.; Lukman, R.; Lozano, F.J.; Huisingh, D.; Lambrechts, W. Declarations for sustainability in higher education: Becoming better leaders, through addressing the university system. J. Clean. Prod. 2013, 48, 10-19. [CrossRef]

15. Vaughter, P.; Wright, T.; Mckenzie, M.; Lidstone, L. Greening the ivory tower: A review of educational research on sustainability in post-secondary education. Sustainability 2013, 5, 2252-2271. [CrossRef]

16. Vasilescu, R.; Barna, C.; Epure, M.; Baicu, C. Developing university social responsibility: A model for the challenges of the new civil society. Proc. Soc. Behav. Sci. 2010, 2, 4177-4182. [CrossRef]

17. Buckler, C.; Creech, H. Shaping the Future We Want: UN Decade of Education for Sustainable Development (2005-2014); United Nations Educational, Scientific and Cultural Organization: Paris, France, 2014; pp. 16-20. 
18. Cabedo, L.; Royo, M.; Moliner, L.; Guraya, T. University social responsibility towards engineering undergraduates: The effect of methodology on a service-learning experience. Sustainability 2018, 10, 1823. [CrossRef]

19. Brennan, J.; King, R.; Lebeau, Y. The Role of Universities in the Transformation of Societies; Synthesis Report; Centre for Higher Education Research and Information/Association of Commonwealth Universities: London, UK, 2004.

20. Smith, L.J.; Chenoweth, J.D. The contributions of student organization involvement to students' self-assessments of their Leadership traits and relational behaviors. Am. J. Bus. Educ. 2015, 8, 279-288. [CrossRef]

21. Kane, C. Advancing student leader development through student organization advising and institutional support. New Dir. Stud. Leadersh. 2017, 155, 59-70. [CrossRef] [PubMed]

22. Lebrón, M.J.; Stanley, C.L.; Kim, A.J.; Thomas, K.H. The empowering role of profession-based student organizations in developing student leadership capacity. New Dir. Stud. Leadersh. 2017, 155, 83-94. [CrossRef] [PubMed]

23. Kodama, C.M.; Laylo, R. The unique context of identity-based student organizations in developing leadership. New Dir. Stud. Leadersh. 2017, 155, 71-81. [CrossRef] [PubMed]

24. Bowman, N.A.; Park, J.J.; Denson, N. Student involvement in ethnic student organizations: Examining civic outcomes 6 years after graduation. Res. High. Educ. 2015, 56, 127-145. [CrossRef]

25. Rosch, D.M.; Collins, J.D. The significance of student organizations to leadership development. New Dir. Stud. Leadersh. 2017, 15, 9-19. [CrossRef] [PubMed]

26. Park, J.J. Clubs and the campus racial climate: Student organizations and interracial friendship in college. J. Coll. Stud. Dev. 2014, 55, 641-660. [CrossRef]

27. Park, J.J.; Kim, Y.K. Interracial friendship and structural diversity: Trends for greek, religious, and ethnic student organizations. Rev. High. Educ. 2013, 37, 1-24. [CrossRef]

28. Chung, J.Y. A critical biculturalist approach to ethnic student organizations. J. Divers. High. Educ. 2015, 8, 30-42. [CrossRef]

29. Von George, T.A. Student Organizations as a Venue for Cross-Racial Interaction; University of Massachusetts Boston: Boston, MA, USA, 2014.

30. Li, F. Research on investigation and countermeasure of students' participation in organizations in social transformation period. China Electr. Power Educ. 2008, 131-133. (In Chinese)

31. Zhao, T. Analysis of status on college students' participation in organizations. Henan Educ. 2012, 25-26. (In Chinese)

32. Chen, X.; Ding, J. An analysis of the relationship between the students' participation in various associations and their socialization process. J. Nanjing Audit Univ. 2010, 89-94. (In Chinese)

33. Li, F. Survey of students' participation in organizations from the comparative perspective between China and Japan. China Youth Study 2017, 112-118. (In Chinese)

34. Hu, S. An empirical study on the quality of college students' participation in organizations. High. Educ. Explor. 2012, 128-133. (In Chinese)

35. Wu, S.; Fan, B. Research on college students' participation in organizations based on psychological contract theory. High. Educ. Explor. 2015, 107-113. (In Chinese)

36. Chen, L.; Xue, L. The influence of participation in organizations on undergraduates' socialization. J. Hebei Radio TV Univers. 2008, 13, 89-92. (In Chinese)

37. Li, Z. Study on the role of the university students society in the construction of campus innovative culture. Theory Pract. Educ. 2013, 27-29. (In Chinese)

38. Qin, J. A Study on the influence of participation in student associations on the employment of college students. J. Natl. Acad. Educ. Admin. 2013, 78-82. (In Chinese)

39. Yang, F.; Li, Z.; Xu, Q. Students' evaluation of student organizations and influencing factors of universities. Educ. Res. 2015, 43-51. (In Chinese)

40. Du, Y.; Bian, R. Research on the impact of university student associations on students and the strategy for development. Theory Pract. Educ. 2017, 20-21. (In Chinese)

41. Ceulemans, K.; Lozano, R.; Alonso-Almeida, M. Sustainability reporting in higher education: Interconnecting the reporting process and organisational change management for sustainability. Sustainability 2015, 7, 8881-8903. [CrossRef] 
42. Disterheft, A.; Caeiro, S.; Azeiteiro, U.M.; Filho, W.L. Sustainability Science and Education for Sustainable Development in Universities: A Way for Transition; Springer International Publishing: Basel, Switzerland, 2013.

43. Gea, A.A.; Tampubolon, S.M.; Lakonawa, P. Developing positive multicultural attitudes in student organization. Adv. Sci. Lett. 2017, 23, 1005-1007. [CrossRef]

44. Agarwal, N.; Calvo, B.; Kumar, V. Paving the Rroad to success: A students with disabilities organization in a univeristy setting. Coll. Stud. J. 2014, 48, 34-44.

45. Kezar, A.; Acuña, A.A.; Drivalas, Y.; Wheaton, M.M. Building social change oriented leadership capacity among student organizations: Developing students and campuses simultaneously. New Dir. Stud. Leadersh. 2017, 55, 45-57. [CrossRef] [PubMed]

46. Munoz, L.; Miller, R.; Poole, S.M. Professional student organizations and experiential learning activities: What drives student intentions to participate? J. Educ. Bus. 2016, 91, 45-51. [CrossRef]

47. Martindale, D.; Olate, R.; Anderson, K.A. Practicing professional values: Factors influencing involvement in social work student organizations. Int. J. High. Educ. 2017, 6, 1-10. [CrossRef]

48. Hoover, E.; Harder, M.K. What lies beneath the surface? The hidden complexities of organizational change for sustainability in higher education. J. Clean. Prod. 2015, 106, 175-188. [CrossRef]

49. Figueiró, P.S.; Raufflet, E. Sustainability in higher education: A systematic review with focus on management education. J. Clean. Prod. 2015, 106, 22-33. [CrossRef]

50. Koffka, K. Principles of Gestalt Psychology. Harbinger Book 1935, 20, 623-628.

51. As a campus culture, Laoxianghui (also named Fellow Townsmen Assocication, that is, a group of students coming from the same province, prefecture or county) is typical at Chinese universities. They may organize thematic activities periodically at the university, and the largest one is usually in September shortly after the new students complete registration. The new students usually ask for seniors' experience, including which organization to join. In addition, each college (division) will also organize similar activities and workshops, and the new students can get more information on courseworks and organizations.

52. Family is the primary living environment for children. According to a survey, more than half of the Chinese families have a mother-dominated education, while less than 20 percent have a father-dominated education [53]. So the mother's perception will have a direct impact on the child's behavior. This result is similar to the findings in Japan [33].

53. Chi, Y. Chinese family education: Mothers pay attention to education in more than half of families while father's absence. Qilu Evening News, 24 October 2016. (In Chinese)

54. Maslow, A. Motivation and Personality; Harper \& Row: New York, NY, USA, 1999; pp. 187-202.

55. Sun, P. The enlightenment of Maslow's Hierarchy of Needs Theory for the ideological and political education of college students. J. Jiangsu Inst. Educ. 2011, 54-56. (In Chinese)

56. Shi, X.; Chen, $X$. Investigation and ponderation on the actuvities of mass organization of contemporary university students. J. Hangzhou Teach. Coll. 2002, 104-107. (In Chinese)

57. Ma, Z.; Kang, S.; Zhang, L.; Tong, L.; Su, X. Analysis of impacts of climate variability and human activity on streamflow for a river basin in arid region of northwest China. J. Hydrol. 2008, 352, 239-249. [CrossRef]

58. Vroom, V.H. Work and Motivation; John Wiley \& Sons: New York, NY, USA, 1964.

59. Roodman, D. Fitting fully observed recursive mixed-process models with cmp. Stata J. 2011, 11, 159-206.

60. Liu, M.; Hu, S. The impact of association participating on university students' subjective well-being. J. Chongqing Univ. Arts Sci. 2012, 31, 63-67.

61. Nicholson, W. Microeconomic Theory: Basic Principles and Extensions; Cengage Learning: Boston, MA, USA, 1978; pp. 370-372.

62. Zhou, N.; Ning, M.; Jiang, H. Bureaucratic style in college students organization. China Youth Daily, 27 July 2009. (In Chinese)

63. Chen, P.; Zhou, S.; Ren, T. College student cadres: Are to act the high and mighty official or serve students. Guangming Daily, 31 July 2018. (In Chinese)

64. Chen, S. Survey and research of community participation of college students. J. Zhejiang Youth Coll. 2009, 45-47. (In Chinese)

(C) 2018 by the authors. Licensee MDPI, Basel, Switzerland. This article is an open access article distributed under the terms and conditions of the Creative Commons Attribution (CC BY) license (http:/ / creativecommons.org/licenses/by/4.0/). 